\title{
Improving postharvest handling of soybean (Glycine Max (L.) Merrill) in Cameroon
}

\author{
Njume Akeme Cyril ${ }^{1 *}$, Kamanga Blair Moses ${ }^{2}$, Widodo Slamet ${ }^{3}$, Purwanto Yohanese Aris ${ }^{4}$ \\ ${ }^{1}$ Department of Agronomic and Applied Molecular Sciences, University of Buea, Buea, Cameroon \\ ${ }^{1}$ International Center for Environmental Education and Community Development, South West Region, Buea, Cameroon \\ 2 Bvumbwe Agricultural Research Station, Limbe, Blantyre, Malawi \\ 1,3,4 Department of Mechanical and Biosystem Engineering, Bogor Agricultural University, West Java, Indonesia
}

\section{Keywords \\ Botanicals \\ Postharvest losses \\ Storage material \\ Soybean \\ Traditional structures}

Received: 3 April 2019

Accepted: 8 May 2019

Published: 10 June 2019

\begin{abstract}
The objective of this review was to determine soybean losses at different stages postharvest handling and to recommend technology intervention for sustainable solutions and maintenance of quality. Secondary data collected globally from published articles, ranging between the years 2000 to 2020 were utilized to determine the causes and to provide technology innovation to abate the problems. Soybean (Glycine max L. Merrill) is one of the most important legume crops in the world due to its uses namely food, feed, oil, and nutrient supplement for humans, livestock, industries, and plants respectively. In Sub-Saharan Africa, the average yield has remained at $1.1 \mathrm{t} / \mathrm{ha}$ compared to $2.4 \mathrm{t} / \mathrm{ha}$ in the world and this region is known for the highest malnutrition and food insecurity in the world. In Cameroon, most of the soybean grains are imported, however, trials are currently been conducted to identify varietal adaptability to scale up production in the different agroecological zones. Stakeholders such as producers, distributors, processors, and consumers are faced with seriously significant postharvest losses along the grain value chain. Both quantitative and qualitative losses were identified with mostly incurred in storage because of biotic and abiotic factors. Technology intervention occurs in the system particularly in storage facilities and packaging such as hermetic and triple packaging respectively is indispensable in reducing postharvest losses. The discovery of effective marketable botanicals for use in storage is invaluable for small-scale producers in Cameroon and other developing countries for grain protection against pests and diseases.
\end{abstract}

(c) 2019 The Author(s). Published by TAF Publishing.

\section{INTRODUCTION}

Soybean (Glycine max (L.) Merrill.) is one of the most important legume crops in the world due to its uses namely food, feed, oil, and nutrient supplements for humans, livestock, industries, and plants respectively. Globally, the economic value of six top-ranked legumes is reported to be over US $\$ 21.8$ billion in export, with $84 \%$ accounting for the total quantity of soybean, followed by common bean (Phaseolus vulgaris) with 8.8\%, groundnut (Arachis hypogaea) 4.9\% and chickpea (Cicer arietinum) 2.4\% [1]. In 2016, the surface area for soybean grown in Sub-Saharan Africa (SSA) increased from 20,000 ha in the early 1970 s to $1,500,000$ ha. This led to a corresponding increase in yield from 13,000 tonnes in the early 1970 s to 2,300,000 tonnes in 2016 [2]. Though, the average yield has remained at $1.1 \mathrm{t} / \mathrm{ha}$ in the last four decades, in contrast to the world average of 2.4 t/ha [3]. Among Africa countries, South Africa is the highest producer of soybean with an estimated production of $2290 \mathrm{~kg} / \mathrm{ha}$, followed by Zambia $1940 \mathrm{~kg} / \mathrm{ha}$, Nigeria 960 $\mathrm{kg} / \mathrm{ha}$, and Uganda $600 \mathrm{~kg} / \mathrm{ha}$ [3]. Others include; Zimbabwe, Malawi, Ghana, Sudan, and Ethiopia, also experienced an increase in commercial soybean expansion. Soybean has a high nutritive value, rich in protein content with an estimation of $40 \%$, lipids content of $20 \%$, bioactive factors, and numerous beneficial nutrients $[4,5]$. In developing countries, soybean is used in fighting malnutrition and

\footnotetext{
${ }^{*}$ Corresponding author: Njume Akeme Cyril

†email: akeme_cyril@apps.ipb.ac.id
} 
food security for millions of people [4, 6]. In Cameroon, due to its nutritive value, it is used for feeding children, patients, aged adults, [7] and as feed (soybean cake) to animals. Also, the oil is used by food industries for baking of cake and bread.

In Cameroon, soybean production is low which may be attributed to lack of high yielding varieties capable of adapting to the different Agroecological Zones (AEZ). However, [8] reported research trails of soybean seeds conducted in 2018/2019 in Cameroon funded by Soybean Innovation Lab (SIL) in partnership with International Institute of Tropical Agriculture (IITA), and the Institute of Agricultural Research for Development (IRAD) to evaluate yield and variety for adaptability. Authors conducted a Pan-African Soybean Variety Trials with 43 varieties imported from eight different seed sources: eight lines from Zimbabwe (Seedco), six lines from Malawi (DARS), ten lines from Zambia (IITA), five lines from Uganda (Makerere University), two lines from Ethiopia (EIAR), six lines from Ghana (CSIR-SARI), and one line from Kenya (KALRO) and demonstrated in four sites in Cameroon including Foumbot, Garoua (Kismatari), Mbalmayo, and Yaounde (Nkolbisson). Cameroon is a SubSaharan African (SSA) country located at the tropical belt of the world, within Central-West Africa and displaying characteristic variations of two climatic zones namely the equatorial and tropical zones $[9,10]$. It is expected that these trails will perhaps increase soybean production in Cameroon and also serves other African countries, due to the variation in the experimental sites in Cameroon. In September 2019, doing Business in Cameroon (Magazine number 87 May 2020) reported in September 2019 that Cameroon soybean production was estimated at 50,000 tonnes per year. Besides this quantity, Cameroon is reported to spend on imports every year an estimated among of US \$24 million. In Cameroon, the stakeholders involved in postharvest operations of soybeans are faced with serious quantitative and qualitative losses because of a lack of knowledge, insufficient technology, poor handling, and storage facilities. These stakeholders include; producers, distributors, processors, and consumers. In African countries, Postharvest Losses (PHL) have been estimated to range between 20 to $40 \%$, which is highly significant because in several parts of Africa crop production is low [11]. Postharvest handling operations are a sequence of activities moving agricultural produce and its derivatives from producers to consumers. The handling system of grains involves a series of activities undertaken to maintain quality and safety from producers to consumers. The main activities in postharvest handling of soybean include; harvest, drying, and storage. Although processing is important it will not be discussed in this paper. During these processes, soybeans are subjected to several biotic and abiotic factors that are responsible for the qualitative and quantitative losses incurred by small-scale producers. These factors categorized into biotic and abiotic such as temperature, relative humidity, oxygen, and carbon dioxide; and bacteria, fungi, insects, and rodents respectively [12]. [13] reported that physical, chemical, and biochemical changes may occur in soybeans due to environmental conditions and the storage duration. While, stakeholders because of poor handling systems and methods, are faced with degradation related to insect pests damage and microbial contaminations. The majority of the PHL incurred by small-scale producers and feed processors are attributed to poor storage facilities and lengthy storage time. It is therefore paramount to recommend technology intervention at various stages in postharvest operations to stakeholders.

\section{A. Objectives of the Study}

The objective of this review was to determine soybean losses at different stages of postharvest and to recommend technology intervention for sustainable solutions and maintenance of quality. Secondary data collected globally from published articles, ranging between the years 2000 to 2020 were utilized to determine the causes and the technology innovation to abate the problems faced by actors in the grain value chain system.

\section{B. Harvesting}

Harvesting is the initial step in postharvest process that deals with detaching soybean pods from the main plant. It is a critical point that determines the crop quality from harvest to end consumers. Harvesting makes use of the maturity index of crop specificity. The maturity stage of soybean determines its quality at harvest, which cannot be improved after except to maintain. Additionally, it depends on whether the variety is early or late maturing. In Cameroon, for instance, [8] observed that of the 43 varieties of PanAfrica soybean variety trail cultivated TGx2006-3F variety matured early in 86 days and TGx1910-14F variety matured late in 101 days. Both varieties were bred by IITA Nigeria. Early and late harvest results in deficiency and loss in nutrients respectively. Moreover, late harvesting predisposed grains to high shattering losses, exposure to birds, insect pests, rodents attack, and other natural calamities such as rain, hailstorms etc. [14]. Furthermore, late harvest allows field-to-storage insect pests to infest the pods and contaminate the grains with fungi spores. Hence, in- 
creasing deterioration in storage which could be avoided by harvesting at the right maturity and period. Unlike in developed countries, most of the harvesting carried out in developing countries are manual which results in high labour intensity, delay harvesting, and increase losses. In India, $10.3 \%$ of paddy loss was recorded in delayed harvesting coupled with a lack of proper harvesting equipment [15]. An ideal harvest moisture content for soybean range between 12 to $14 \%$. Lower moisture content will result in more losses due to shattering and threshing damage [16]. Besides, soybean is harvested with a moisture content that ranges between $16 \%$ to $18 \%$ wet base (w.b) and proceed with drying [17]. There are 3 types of harvest losses encountered during harvest namely; pre-harvesting, gathering, threshing, and cleaning losses. [18] explained these losses as follows: a) Preharvest losses occur when seed or pods detached from the stalk are found on the ground before harvest. These losses are due to natural causes, mainly shattering and broken stalks which can be reduced by harvesting at the right period, b) gathering losses occur when all the seeds or harvest pods are not put together. There are three types encountered such as shatter losses, shelled seeds, and detached pods from the pods and stalk respectively. These are shattered in the field without combining; stubble losses, seeds and pods from the plant biomass, and c) threshing and cleaning losses result from operations that separate seeds from pods and remove dirt found in seeds. During threshing losses, unthreshed seeds remain in pods pass through de-husk machines whereas other seeds are cracked by the cylinder. Meanwhile, cleaning losses are observed at sorting using rack and sieve. Furthermore, [18] reported that harvest loss could range from 10 to $20 \%$ and a loss below $5 \%$ is acceptable whereas loss of $3 \%$ is considered an excellent harvest.

\section{Drying Process}

Drying is a postharvest process involving the transfer of heat and the removal of water from the material by circulating hot air on it. The amount of moisture content determines the storage duration and quality of grains in storage. [17] explained that the main goal of soybean drying is to reduce the excess moisture content in the grains, preventing degradation from biotic and abiotic factors. This makes it hard for insect pests to damage grains with lower moisture content in storage due to a hardened surface. According to [19], moisture content for safe soybean storage that could assure good quality ranges between $10 \%$ to $12 \%$ wet base (w.b). Drying is broadly categorised into two methods: natural drying and artificial drying [20]. Natural drying is also known as sun drying is a traditional practice that is carried out in an open environment that could either be directly under the sun or in a shade. Sun drying is characterized by high labour intensity, lengthy time to dry, huge losses and depends on the weather condition. This open-air drying method exposes grains to birds, insects, and contaminants such as stones, dust, and foreign materials [20]. Over the years, Polyethylene (PE) bags have been utilized for grain drying. Cloudy, humid, and wet weather restricts adequate drying and causes grains to be stored at high moisture, leading to high losses caused by the growth microorganisms. Unlike in developed countries, wet regions in Africa recorded high grain damage due to poor weather conditions and inadequate storage infrastructures [21].

Artificial or mechanical drying is an advanced technique of drying mostly practiced by developed countries namely; oven drying, freeze-drying (lyophilization), spray drying, microwave drying, radiofrequency drying and infrared drying $[22,23]$. Some of the limitations encountered in natural drying are addressed by mechanical drying such as a proper reduction in excel moisture, control of air temperature and maximized drying space. Although beneficial, stakeholders in developing countries rarely utilized this technique because of the following high initial and maintenance costs, insufficient availability of equipment, and lack of operational knowledge [24]. In recent decades, in Africa and other developing countries, solar dryers used for frying are designed into simple (Figure 1 left) and greenhouse model (Figure 1 right). These systems could be advanced by harnessing the solar energy, stored in a battery and used during poor weather conditions. In Cameroon, solar dryers are used in drying crops such as cocoa (Theobroma cacao), coffee (Coffea spp.), corn (Zea mays), soybean, cowpea (Vigna unguiculate), wheat (Triticum spp.), egusi (Cucumeropsis mannii) and rice (Oryza sativa). [25] compared the performance of wood-fuel oven, a greenhouse solar dryer, and open sun drying techniques for drying of fermented cocoa beans, under the same weather conditions in 2017 at Bafia, Southwest Region of Cameroon. [25] observed that the quality of beans produced through open-air drying and greenhouse solar dryer (Figure 1 right) had good colour, and a pleasant chocolate flavour and taste compared to wood-fueled. Solar dryers are constructed either with wood (Figure 1) or metallic materials (Figure 2). 


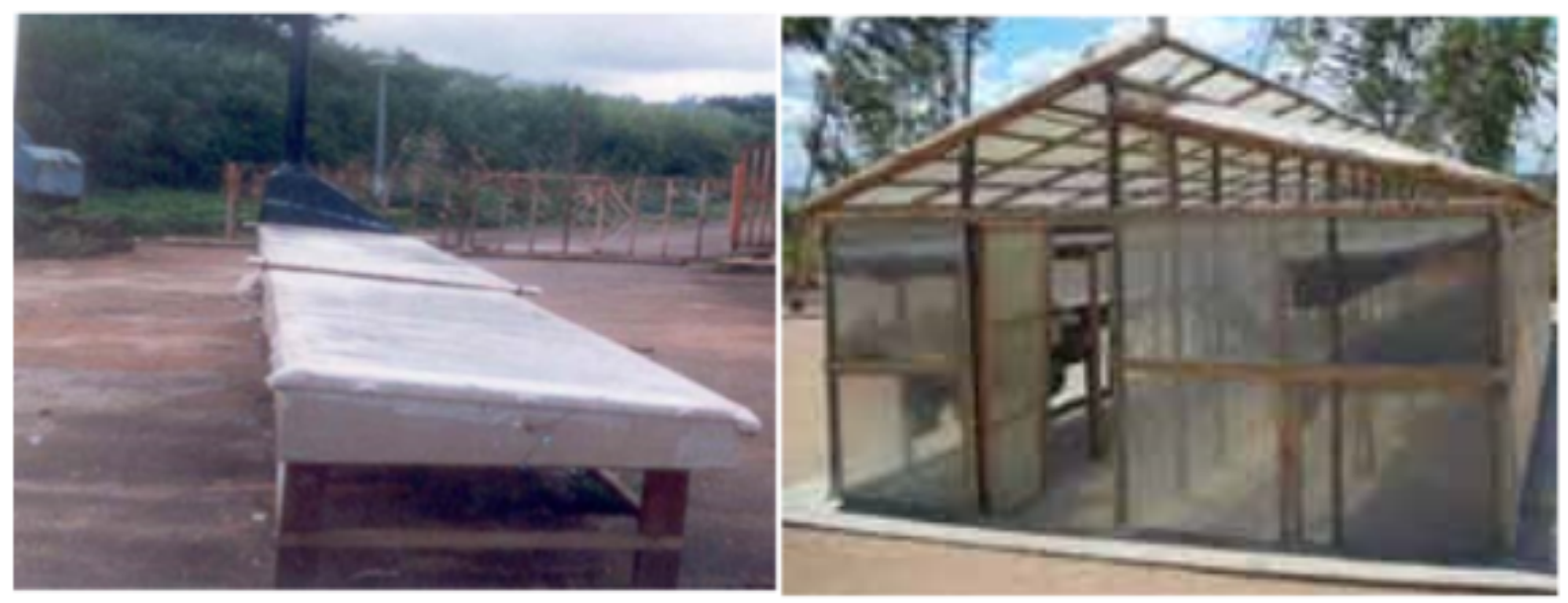

Fig. 1. Simple solar dryer (left) and greenhouse solar dryer (right)

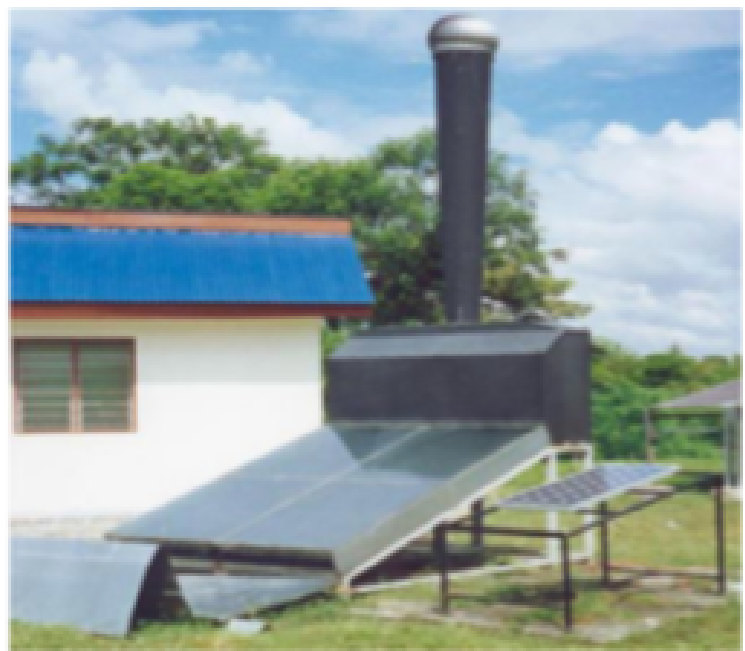

Fig. 2. Advance solar dryers [26] (a) Cameroon solar dryer

Maintenance of grain quality depends on the temperature and flow rate of hot air, but the drying rate is influenced by moisture content and the temperature of the storage environment. Ideally, soybeans should be dried to $12 \%$ or $13.0 \%$, depending on whether they are stored to be marketed directly or for several months [17]. Besides, the moisture content at storage may influence the rate of seed germination. [27] reported a decrease in seed germination rate by $17 \%$ and $38 \%$ in 3 and 6 months of storage and seed vigour reduction by $23 \%$ and $71 \%$ for three soybean varieties. The reason which could be attributed to this effect is an increasing temperature ranging from 22.6 to $28.8^{\circ} \mathrm{C}$ [27]. Soybean should be dried at a gentle temperature to avoid degradation of nutrition and crack during threshing [17].

\section{Soybean Storage}

Storage is a postharvest process whereby agricultural produce and its derivatives are kept for future use. It is a transit stage of agricultural produce and its derivatives from pro-

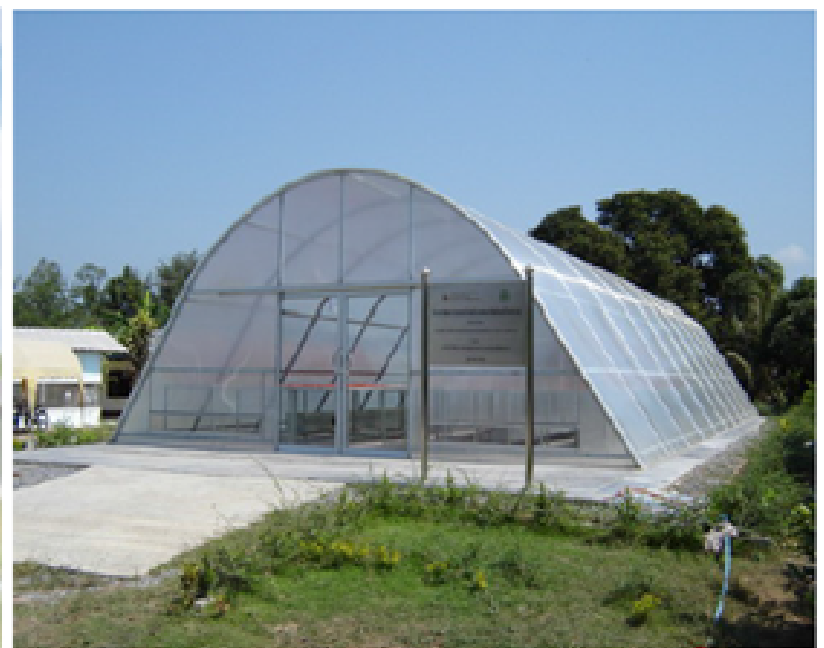

(b) Vegetable solar dryer in Thailand

ducers or distributors to consumers. In African countries, more than $70 \%$ of harvested grains are stored for home consumption and surplus for marketing [28, 29]. Grains are stored from one season to the next to have a constant supply all year round. The general period of grain storage in Cameroon and other African countries ranges between 3 to 12 months [21]. Moreover, the length of storage depends on the AEZ, ethnic group, quantity to be stored, environmental storage conditions, available storage facilities, and the state of the product [30]. Storage aimed at preserving the quality attributes that grains present after harvest [12]. In Cameroon, there are five AEZ (Table 1) characterized by variations, that may influence the duration of storage, quality, and safety of soybean. For example, in Sudan and Guinea Savanna in Nigeria, the length of grain storage ranges between a 1 to 2, except soybean with less than 5 months of storage because of its high demand [31]. 
TABLE 1

THE FIVE AGROECOLOGICAL ZONE (AEZ) IN CAMEROON [32]

\begin{tabular}{llll}
\hline \hline AEZ (Districts) & Rainfall (mm) & Elevation (h.a.s.l) & Mean Annual (Temp.) \\
\hline I Sudano-sahelian zone (Garoua) & $500-900$ & $250-500$ & $28^{\circ} \mathrm{C}$ \\
II High Guinea savannah (Ngaoundere) & $1,500-1,800$ & $500-1,500$ & $23^{\circ} \mathrm{C}$ \\
III Western highlands (Foumbot, Baham, Dschang, Mbouda, Bamougoum) & $1,800-2,400$ & $1,500-2,500$ & $21^{\circ} \mathrm{C}$ \\
IV Humid forest (monomodal rainfall) (Buea, Melong) & $2,000-11,000$ & $0-2,500$ & $26^{\circ} \mathrm{C}$ \\
V Humid forest (bimodal rainfall) (Yaounde, Okola, Obala, Bafia, Akonolinga) & $1,500-2,000$ & $400-1,000$ & $25^{\circ} \mathrm{C}$ \\
\hline \hline
\end{tabular}

Note: H. A. S. 1 is the height above sea level; Temp is temperature and $\mathrm{mm}$ is millimeter

1) Storage structures: Soybean quality and safety can be acceptable by consumers most often within a year. Degradation of characteristics increases in storage as a result of variation of environmental conditions such as temperature, relative humidity, moisture content of material, and permeability of storage containers. To some degree, the external environmental condition may influence the internal process and reactions.

The mud rhombus storage has a short duration of grain storage [33]. The structure is cylindrical, spherical or circular-shaped storage and is constructed on stones that serve as based for suspension (Figure 3 left). Mud rhombus is mostly used for grain storage in the AEZ I SudanoSahelian in Cameroon (Table 1) with lower rainfall. A thatched or aluminum sheet structure should be constructed above to shield it from harsh weather condi-

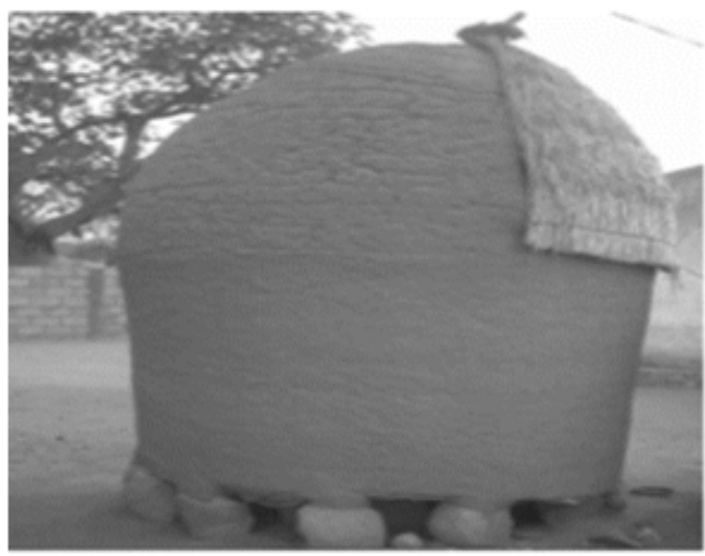

Fig. 3. Mud rhombus (left) and clay pots (right) photos by [21] [35]. tions: rainy and dry season. It prevents temperature variation which occurs within a day (morning, afternoon, and evening) i.e., warming and cooling from reducing the shelf life and edible quality. [34] reported an increase in texture hardness with soybean grains of different Moisture Content (MC) 9,11 , and $13 \%$ and temperatures 10,20 , and $30^{\circ} \mathrm{C}$. The researcher observed that the $\mathrm{MC}$ of $13 \%, 10^{\circ} \mathrm{C}$ versus MC $13 \%, 30^{\circ} \mathrm{C}$ had a significant increase in cooked hardness of 23.2 to 23.4 , and 24.9 to 38.4 respectively. Besides, the mud rhombus needs to be raised on a concrete floor of about $0.5 \mathrm{~m}$ to prevent topping down due to rainfall-runoff. This storage system is not airtight and moisture is generated from biochemical reactions triggered by the interaction between biotic and abiotic factors. Damages are influenced by rodents, insects, structural failure, and termites

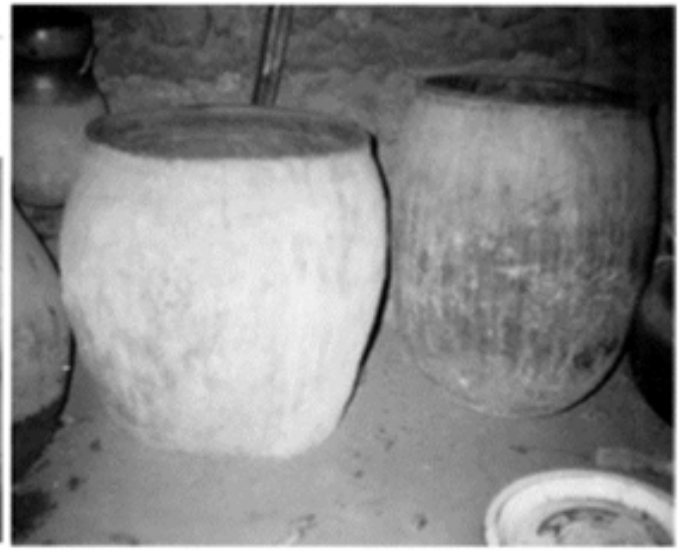

immediately after harvest. Earthen pots (Figure 3 left) and gourds (Figure 4 right) are non-airtight traditional materials that permit the exchange of gases (oxygen and carbon dioxide). Soybean is oxidized by oxygen in a process of aerobic respiration to produce carbon dioxide, moisture, and heat [36]. cultivate during the rainy in AEZ II, III, and V usually build temporary storage of grains and cobs for maize on-farm for

$$
\mathrm{C}_{6} \mathrm{H}_{12} \mathrm{O}_{6}\left(s_{2}\right)+6 \mathrm{O}_{2}(g) \rightarrow 6 \mathrm{CO}_{2}(g)+6 \mathrm{H}_{2} \mathrm{O}_{(l)}+686 \mathrm{kj} / \mathrm{mol}
$$


The moisture generated inside the container creates a suitable microclimate for microorganisms and insect pests to thrive, thereby reducing the shelf life and quality. The major postharvest grain storage fungi are; Aspergillus spp., Fusarium, and Penicillium spp.
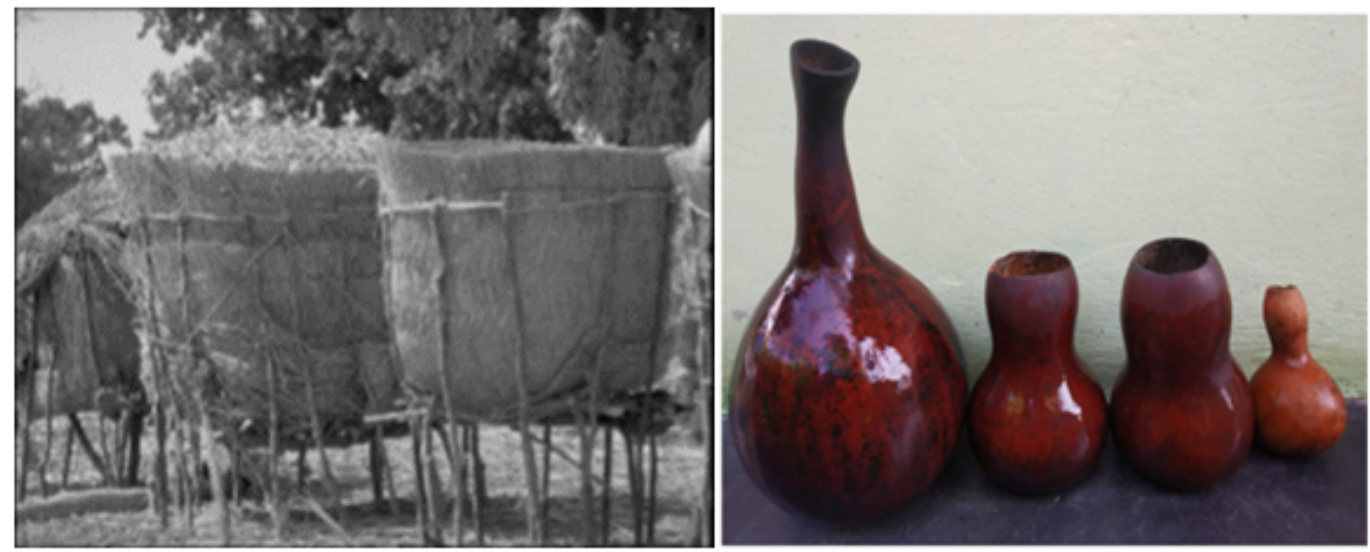

Fig. 4. Woven basket (left) and Gourd (right) in Cameroon photos by [21]

High relative humidity with varying environmental conditions makes drying of grains difficult by farmers in AEZ IV. Formerly, the seasons could be predicted, March making the start of the rainy season but the current climate change has left farmers confused. Nowadays, the start of the rainy season range between March to May, thereby making production and postharvest operations difficult. However, due to the unpredicted weather conditions and high precipitation, farmers have resolved in constructing cribs made from raffia palms and bamboo materials (Figure 5 left) for drying using ambient ton-farm. In contrast, farmers who financially viable used metallic silo after drying for storage (Figure 5 right). The metallic silo is coated with an anti-rust substance, preventing food contamination [37] while others lined Polyethylene (PE) inside. Additionally, plastic airtied containers appropriate for storage are utilized.

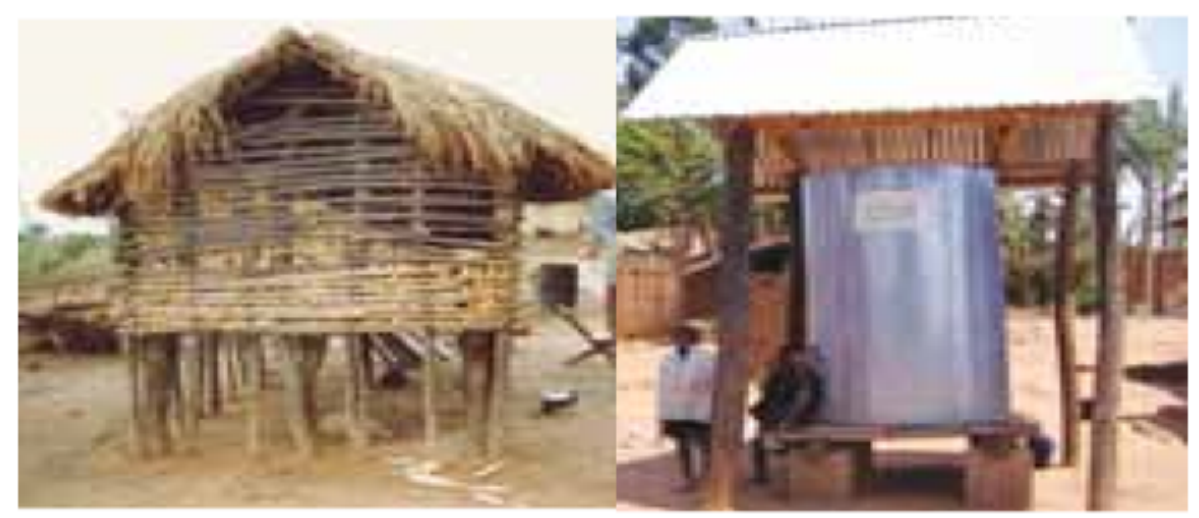

Fig. 5. Crib (left), and metal silo (right), photos by [38]

In some communities, farmers organized themselves to form cooperative, combining resources to improve on production and market. Harvests are gathered in the cooperative building where sales are done to processors (Figure 6 left). Unfortunately, some of these community halls are earthen-floor which predisposes bagged or unbagged grains to contamination and degradation (Figure 6 right). Pallet stands of approximately $10 \mathrm{~cm}$ could be used to abate the absorption of moisture from the earthen-floor (Figure 6 right). On the other hand, concreted-floor ease movement of the wheelbarrow, easy clearing of dirt and debris, and prevent rats from digging holes through the floor from out- side. Also, the easy application of treatments or baits to control microbial, insect pests, and rodents. Hermetic storage is gaining popularity in developing countries for the storage of cocoa, coffee, cowpea, soybean, maize, and rice, prolonging shelf life with maintaining quality. [39] reported another technology called triple bagging used to store cowpea in West and Central Africa in the following countries Benin, Burkina Faso, Cameroon, Mali, Niger, Nigeria, and Senegal. Results recorded from this study gave a significant profit margin ranging from US $\$ 1,470,139$ to $\$ 198,917,911$ million per year. 


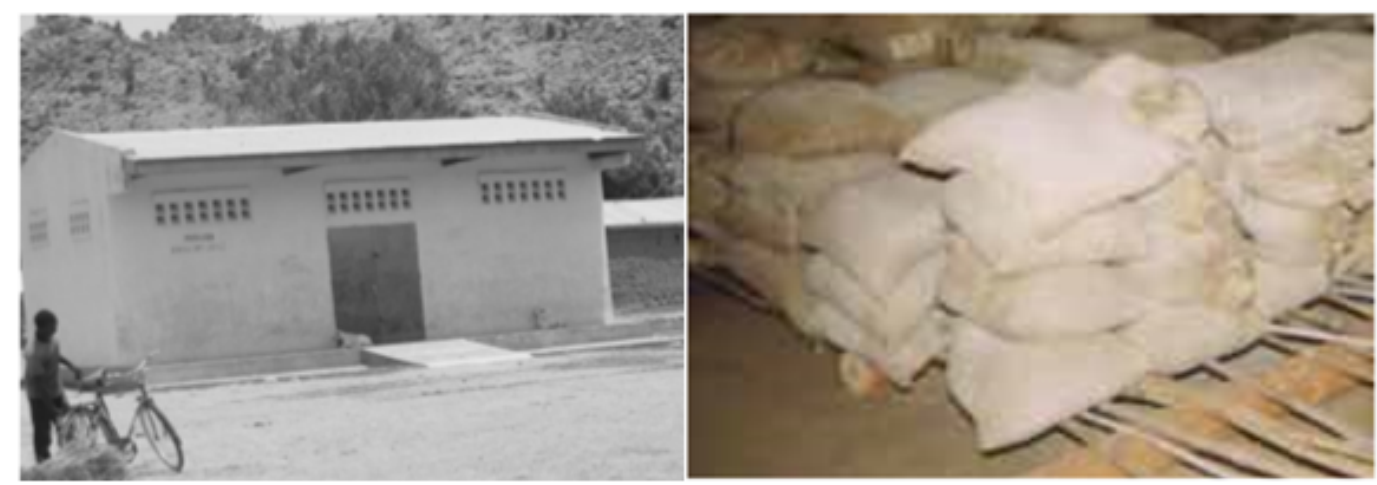

Fig. 6. Crib (left), and metal silo (right), photos by [38]

In developing countries, distributors and processors used locally available materials for storage and transportation of grains i.e., cereals and pulses. Some of these materials include; PE bags, jute bags, metal silos, drums, and her- metic bags. Currently, developing countries namely South Africa, Ghana, Philippines, India, etc used hermetic storage for storage and shipping (Figure 7).

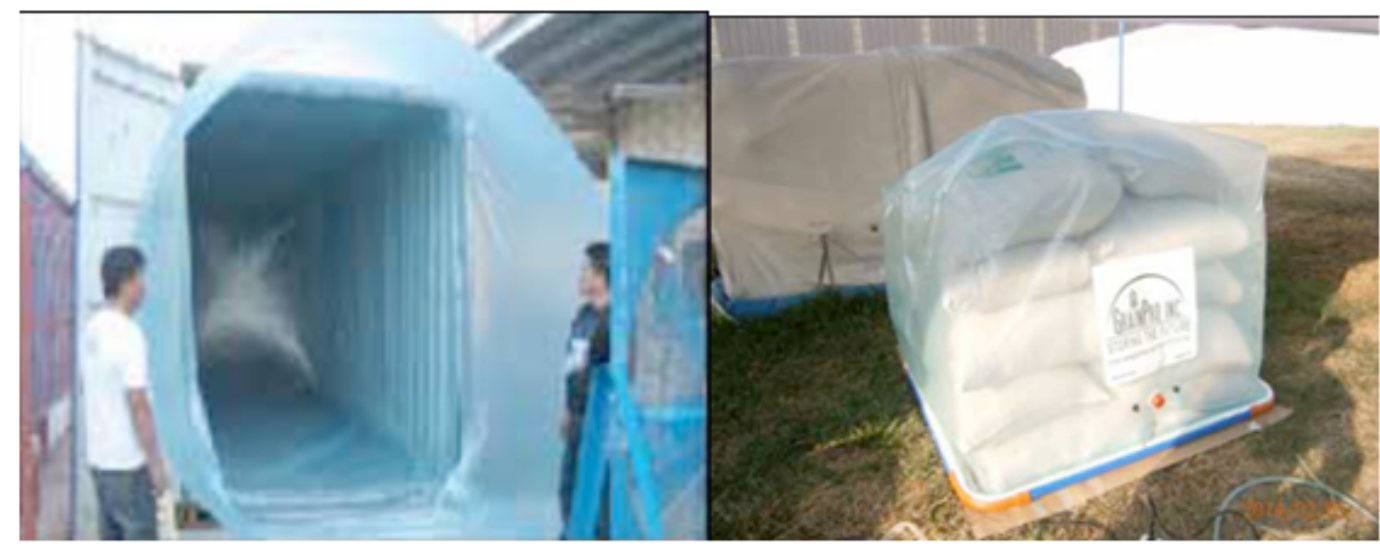

Fig. 7. Distribution (left) and storage of soybean using GrainPro TranSafeliner (right) Photos by [40]

2) Storage problems of soybean: Storage losses are categorised into two main factors namely biotic and abiotic. Abiotic factors include packaging material, temperature, relative humidity, and rainfall; and biotic factors include micro-organism, rodents, birds, and insect pests [41]. The maximum amount of losses incurred during the storage of grains is lacked of infrastructure [20]. Meanwhile, grain losses can be classified into direct losses that relate to physical loss and indirect losses: loss in quality and nutrition. During storage, insects could cause damage and losses which warrant evaluation of the quality and nutritional loss. Therefore, it is important to consider both damage and losses caused by insects during storage instead of only weight loss. "Damage" refers to physical evidence of degradation seen as tunnels on and in the grains. While, "Loss" is the total disappearance of the food, which can be measured quantitatively [42].

3) Abiotic factor: In a traditional system of storage, the majority of the losses occur due to poor sanitation [21]. During the refilling of the container with new grains, the old grains are never removed completely which serves as an inoculum to infest the fresh grains. [43] reported that most storage mould grew very fast at temperatures ranging from 20 to $40{ }^{\circ} \mathrm{C}$ and relative humidity of more than $70 \%$. In contrast, low levels of moisture content and $70 \%$ relative humidity may limit the growth of fungi [20]. [21] reported that Africa traditional storage structures expose grains to insect pests' attacks coupled with appropriate environmental conditions enabling microbial proliferate. Besides, the major problem is the presence of only one entering point for filling and removing grains and could serve as a point of contamination and entry of insect pests [35,44]. Materials made from plant materials are easily destroyed by rodents which serve as a site for infestation.

4) Storage climate: The storage climate depends on both the internal and external variations including temperature, relative humidity, and moisture content of the product. Therefore, the rate of degradation depends on storage conditions and the rate of biological activities. [45] reported that the level of moisture in grains and appropriate higher 
temperature favours insect and fungal development, resulting in a decrease in the germination potential of it. Temperature and relative humidity observed in a soybean stored for 3 and 6 months were high and fluctuating in an ambifaent atmosphere. These conditions contributed to the increase in moisture and 1000 seed weight [27]. Furthermore, [27] observed in storage a reduction of the percentage of the lipid content of soybean grains by $0.37 \%$ and $0.44 \%$ for 3 and 6 months respectively. Also, researchers observed a corresponding increase in protein content from $0.23 \%$ to $1.77 \%$. Therefore, most important storage factors that influence respiration rate, amount of carbon dioxide available, surrounding moisture, heat dissipated are temperature, moisture content in the product, and amount of oxygen.

5) Biotic factors: These are living organisms including; insects, rodents, birds, and microorganisms which cause serious damage in Africa traditional storage systems and developing countries worldwide. Insect pests are field-tostorage, the infestation starts in the field and proceeds in storage. Pulses, oilseeds, and cereal crops share common insect pests of the order Coleoptera and Lepidoptera [21]. Among the biotic factors, insects are the most economically important, cause huge losses in grains of an estimated range of $30 \%-40 \%[11,46,47]$. [48] registered $80 \%$ to $90 \%$ of storage grain losses caused by insects in Togo. Whereas in Nigeria Callosobruchus maculatus (F.), a common pulse weevil has been found responsible for $24 \%$ losses in stored pulses [47]. [47] reported In the Western Highland of Cameroon that $12 \%$ to $44 \%$ of stored maize losses were caused by insect pests. Insects have a variation of hosts, as such an insect feeding on cereals is capable of feeding on pulses and oilseeds. Sub-Saharan Africa is considered suitable for insects because of its good environmental conditions. However, [1] reported the three most important stored grain insect pests in Africa are in the genera bruchids namely Acanthoscelides, Zabrotes, and Callosobruchus. Also, researchers reported that of cereals for grain weevils and grain moth to be Sitophilus spp. and Sitotroga cerealella. In Eritrea, the economic important insect pest of chickpea is Callosobruchus chinensis L. [49]. Meanwhile, Sitophilus spp. destroyed wheat and sorghum grains in storage, and followed by flour beetles (Tribolium confusum Jacquelin du Val), sawtoothed grain beetles (Oryzaephilus surinamensis L.) and mites [49]. In Namibia, the pearl millet grains are hugely destroyed by Corcyra cephalonica Stainton, from Lepidoptera and Pyralidae as order and family respectively [21]. Moth produced masses of silk (web) as they feed through the grains, and also massive destruction of the seeds' embryos [21]. The larvae fed on the embryos where the majority of grain nutrients are trapped, leading to qualitative and quantitative losses of nutrients and weight respectively.

6) Microbiology: Nowadays, mycotoxin contamination is a serious issue in stored grains with a detrimental effect oo the health of humans and animals. Mycotoxins are food contaminants in the food value chain [50]. Mould produced odour, reduced starch content, sugar contents, increased fatty acid content, alters the taste, aroma, and decreases the glossiness of the colour [51]. Besides contaminations, the germination potential of seeds is drastically affected by mould. The most important and common mycotoxins found in grains are Aflatoxins, Fumonisins, Deoxynivalenol, and Ochratoxin [52,53]. Aflatoxins are secondary metabolites that are produced by Aspergillus flavus and A. parasiticus and are considered the most devastating mycotoxins, because of its high potential to cause liver cancer and decline in young children growth $[54,55]$. In developing countries, high grain contamination was estimated at 4.5 billion of persons, known to be affected by aflatoxins $[51,56]$. Several health complications of diseases and death are caused by aflatoxicosis result of a high concentration of aflatoxins [57]. In Africa and Asian countries continents, farmers traditionally/locally use botanicals (plant extracts) for the control of insect pests. These natural pesticides are biodegradable, environmentally friendly, and relatively safe for human health [20]. Several plant extracts are utilized in Cameroon including ash, African bush pepper (Piper guineense), cow dung, and Neem (Azadirachta indica) plant, leaves of African bush pepper, essential oils and chilli pepper [21, 58, 59, 60, 61].

The synthetic insecticide has gained popularity and usage due to its efficacy and quick response in reducing the pest population. Though effective, stakeholders in grains postharvest management have limitations with synthetic insecticides including high costs, inappropriate application leads to pest-resistance, health hazards due to toxic residues, and negative environmental externalities. Unlike in developing countries, fumigation is the major postharvest treatment to storage grains used in developed countries by a trained specialist, with the use of sophisticated equipment to prevent hazards $[47,62]$. In some years ago, some African countries are currently using this treatment technology namely Cameroon, South Africa, Kenya, Nigeria, and Ghana $[60,63,64,65,66]$. Phostoxin is applied only by a licensed technician because of its high toxicity level. In some parts of Africa, farmers are allowed to use a mixture of pirimiphos-methyl (Actellic) and permethrin, commercially 
sold as Actellic Super [67]. Methyl Bromide (MB) and phosphine are the most commonly used chemicals in developing countries [62].

\section{CONCLUSION}

Postharvest operations are carried out to maintain the quality of agricultural produce and its derivatives. Therefore, quality of grains cannot be improved after harvest rather maintained through proper postharvest handling techniques including harvesting, drying, packaging, and/or storage and sanitation. Hence, postharvest losses of grains for example soybean can be reduced by observing proper sanitation and better handling along the value chain. Traditional structures are responsible for most of the storage losses incurred in postharvest grains in Cameroon and developing countries. The factors that aggravate these losses are classified into two groups namely; abiotic and biotic factors. In Cameroon, the postharvest handling system of soybean can be improved by adapting to proper harvesting, use of solar drying technique and/or grains should be stored with moisture content ranging between $12-13 \%$ and improvement of storage materials. Technology intervention in the different stages of handling is indispensable for mitigating postharvest losses to a threshold level to alleviate poverty and malnutrition. Also, this technology intervention should be an improvement of the current method for easy adoption rather than new ideas which can create more confusion and farmers may be hesitant to adopt it. Research to produce effective and marketable botanical products should be prioritized in developing countries because it is environmentally friendly and non-toxic to the health of humans. Hermetic storage and triple packaging should be promoted due to its efficient and effective results in the field.

\section{REFERENCES}

[1] T. Abate, A. D. Alene, D. Bergvinson, B. Shiferaw, S. Silim, A. Orr, and S. Asfaw, Tropical Grain Legumes In Africa And South Asia: Knowledge And Opportunities. London, UK: International Crops Research Institute for the Semi-Arid Tropics, 2012.

[2] United State Department of Agriculuture, "Oil seeds: World markets and trade," 2017. [Online]. Available: https://bit.ly/3gVE0SC

[3] D. M. Khojely, S. E. Ibrahim, E. Sapey, and T. Han, "History, current status, and prospects of soybean production and research in Sub-Saharan Africa," The Crop Journal, vol. 6, no. 3, pp. 226-235, 2018. doi: https://doi.org/10.1016/j.cj. 2018.03.006

[4] G. Singh, The Soybean: Botany, Production and Uses. Wallingford, UK: CABI, 2010.

[5] V. Chernenok, A. Kurishbayev, A. Kudashev, and Y. Nurmanov, "Diagnostics and optimization of crops' nitrogen nutrition in rainfed conditions of the Northern Kazakhstan," Journal of Applied and Physical Sciences, vol. 1, no. 1, pp. 1-8, 2015. doi: https://doi.org/10.20474/-japs1.1.1

[6] S. Ibrahim, "Agronomic studies on irrigated soybeans in central Sudan: I. effect of plant spacing on grain yield and yield components," International Journal Agriculture Sciences, vol. 2, no. 8, pp. 733-739, 2012.

[7] A. Yaouba, G. R. Youatchui, I. Nchoutnji, S. Serferbe, and N. M, 'Seed mycoflora of soybean varieties and field resistance evaluation to soybean rust," International Journal of Botany and Research, vol. 6, no. 3, pp. 1-8, 2016.

[8] N. D. Nicholas, N. N. James, K. N. Florence, T. Phinehas, S. Yechalew, M. Dennis, C. Godfree, W. Roen, T. Abush, and Buyantanshi, Pan-African Soybean Variety Trials. Yaounde, Cameroon: Feed the Future, Soybean Innovation Lab (SIL), 2019.

[9] M. Tingem, M. Rivington, G. Bellocchi, and J. Colls, "Crop yield model validation for Cameroon," Theoretical and Applied Climatology, vol. 96, no. 3-4, pp. 275-280, 2009. doi: https://doi.org/10.1007/s00704-008-0030-8

[10] S. Nadyrov, G. Geldyena, G. Nussupova, and A. Skakova, "Geographical aspects of organizing natural resource management structure in Kazakhstani section of a new economic zone of the silk road," International Journal of Applied and Physical Sciences, vol. 2, no. 3, pp. 59-64, 2016. doi: https://doi.org/10.20469/ijaps.2.50001-3

[11] A. B. Abass, G. Ndunguru, P. Mamiro, B. Alenkhe, N. Mlingi, and M. Bekunda, "Post-harvest food losses in a maize-based farming system of semi-arid savannah area of Tanzania," Journal of Stored Products Research, vol. 57, pp. 49-57, 2014. doi: https://doi.org/10.1016/j.jspr.2013.12.004

[12] D. B. Brooker, F. W. Bakker-Arkema, and C. W. Hall, Drying and Storage of Grains and Oilseeds. London, UK: Springer Science \& Business Media, 1992.

[13] R. Narayan, G. Chauhan, and N. Verma, "Changes in the quality of soybean during storage: Part 1-effect of storage on some physico-chemical properties of soybean," Food Chemistry, vol. 27, no. 1, pp. 13-23, 1988. doi: https://doi.org/10. 1016/0308-8146(88)90032-5 
[14] U. K. Balcoh, "Wheat: Post-harvest operations," 2010. [Online]. Available: https://bit.ly/2ZkFQ9P

[15] E. Kannan, P. Kumar, K. Vishnu, and H. Abraham, "Assessment of pre and post harvest losses of rice and red gram in Karnataka," Crops, vol. 44, no. 6, pp. 61-70, 2013.

[16] A. O. Aof, Better Soybeans Manua. Sydney, Australia: Australia Soybean Production, 2013.

[17] S. Sammy, "On-farm drying and storage," in Arkansas Soybean Production Handbook. Arkansas, AR: Research and Extension, 2014.

[18] H. H. James and J. B. Morris, Part V: Harvesting, Drying, Storage, and Marketing in Soybean Production in Kentucky. Kentucky, KY: Cooperative Extension Service, 2002.

[19] Z. Yang, E. Zhu, and Z. Zhu, "Water desorption isotherm and drying characteristics of green soybean," Journal of Stored Products Research, vol. 60, pp. 25-30, 2015. doi: https://doi.org/10.1016/j.jspr.2014.10.006

[20] D. Kumar and P. Kalita, "Reducing postharvest losses during storage of grain crops to strengthen food security in developing countries," Foods, vol. 6, no. 1, pp. 8-15, 2017. doi: https://doi.org/10.3390/foods6010008

[21] E. Nukenine, "Stored product protection in Africa: Past, present and future," Julius-Kühn-Archiv, vol. 56, no. 425, pp. 26-30, 2010.

[22] N. Ahmed, J. Singh, H. Chauhan, P. G. A. Anjum, and H. Kour, "Different drying methods: Their applications and recent advances," International Journal of Food Nutrition and Safety, vol. 4, no. 1, pp. 34-42, 2013.

[23] R. Guiné, "The drying of foods and its effect on the physical-chemical, sensorial and nutritional properties," International Journal of Food Engineering, vol. 2, no. 4, pp. 93-100, 2018. doi: https://doi.org/10.18178/ijfe.4.2.93-100

[24] H. R. Alavi, Trusting Trade and the Private Sector for Food Security in Southeast Asia. New York, NY: The World Bank, 2011.

[25] B. B. Marguerite, V. E. Judith, K. T. Charles, H. Y. Fidele, A. Koue, E. N. Nathalie, H. Rachid, B. M. Mary, A. N. Leopold, H. S. Ntiege, and N. N. Sylvanus, "Comparison of the performance of three cocoa bean drying techniques in Bafia, South West Region, Cameroon," Journal of Life Sciences, vol. 13, no. 5, pp. 25-34, 2019. doi: https://doi.org/10.17265/1934-7391/ 2019.02.004

[26] S. Janjai et al., "A greenhouse type solar dryer for small-scale dried food industries: Development and dissemination," International Journal of Energy and Environment, vol. 3, no. 3, pp. 383-398, 2012.

[27] O. Isaac, E. Seweh, S. Apuri, B. Banful, and S. Amoah, "Effect of storage periods on seed quality characteristics of three soybean (Glycine max (L) Merrill) varieties," International Journal of Scientific Research in Science, Engineering and Technology, vol. 2, no. 4, pp. 823-831, 2016. doi: https://doi.org/10.31274/etd-180810-343

[28] D. Bouhot and A. Mallamaire, The Main Diseases of Plants Cultivated in Senegal. New York, NY: Sage Publications, 1965.

[29] A. Talabi, "A review of the roles of the three tiers of government on project implementation," in A Paper Presented at the NADC Meeting, Port Harcourt, Nigeria, 1989.

[30] L. Ngamo, "Protection intégrée des stocks de céréales et de légumineuses alimentaires: Analyses scientifiques,' Bulletin Panafricain d'Informations Phytosanitaires, vol. 26, no. 27, pp. 13-15, 2000.

[31] M. Ivbijaro, "Evaluation of existing storage systems for grains and tubers and loss estimates at different points in the distribution and marketing chain," Federal Department of Agriculture, Peat Marwick Management Consultants, Lagos, Nigeria, Technical Report, 1989.

[32] G. Mahbou Somo Toukam, G. Cellier, E. Wicker, C. Guilbaud, R. Kahane, C. Allen, and P. Prior, "Broad diversity of ralstonia solanacearum strains in Cameroon," Plant disease, vol. 93, no. 11, pp. 1123-1130, 2009. doi: https://doi.org/10.1094/ pdis-93-11-1123

[33] A. J. Mobolade, N. Bunindro, D. Sahoo, and Y. Rajashekar, "Traditional methods of food grains preservation and storage in Nigeria and India," Annals of Agricultural Sciences, vol. 64, no. 2, pp. 196-205, 2019. doi: https://doi.org/10.1016/j. aoas.2019.12.003

[34] A. M. Yousif, "Soybean grain storage adversely affects grain testa color, texture and cooking quality," Journal of Food Quality, vol. 37, no. 1, pp. 18-28, 2014. doi: https://doi.org/10.1111/jfq.12064

[35] B. Adejumo and A. Raji, "Technical appraisal of grain storage systems in the Nigerian Sudan Savanna," Agricultural Engineering International Journal, vol. 4, no. 6, pp. 45-60, 2007.

[36] M. L. Cardoso, R. E. Bartosik, J. C. Rodríguez, and D. Ochandio, "Factors affecting carbon dioxide concentration in interstitial air of soybean stored in hermetic plastic bags (silo-bag)," in Proceedings of the 8th International Conference on 
Controlled Atmosphere and Fumigation in Stored Products, New Dehli, India, 2008.

[37] D. L. Cederberg, M. Christiansen, S. Ekroth, J. Engman, B. Fabech, K. Guðjónsdóttir, J. T. Håland, I. Jónsdóttir, P. Kostaomo, and C. Legind, Food Contact Materials-Metals And Alloys: Nordic Guidance For Authorities, Industry And Trade. Oslo, Norway: Nordic Council of Ministers, 2015.

[38] P. Golob, "On-farm post-harvest management of food grains: A manual for extension workers with special reference to Africa," in Agricultural and Food Engineering Training and Resource Materials, Rome, Italy, 2009.

[39] B. Moussa, J. Lowenberg-DeBoer, J. Fulton, and K. Boys, "The economic impact of cowpea research in West and Central Africa: A regional impact assessment of improved cowpea storage technologies," Journal of Stored Products Research, vol. 47, no. 3, pp. 147-156, 2011. doi: https://doi.org/10.1016/j.jspr.2011.02.001

[40] T. De Bruin, P. Villers, and S. Navarro, "Worldwide developments in ultra hermetic ${ }^{\mathrm{TM}}$ storage and solar drying technologies," in 11th International Working Conference on Stored Product Protection, California, CA, 2010.

[41] G. Scotti, G. Scialfa, N. Colombo, and L. Landoni, "Magnetic resonance diagnosis of intramedullary tumors of the spinal cord," Neuroradiology, vol. 29, no. 2, pp. 130-135, 1987. doi: https://doi.org/10.1007/bf00327537

[42] J. Kaminski and L. Christiaensen, Post-Harvest Loss In Sub-Saharan Africa-What Do Farmers Say? New York, NY: The World Bank, 2014.

[43] M. Abedin, M. Rahman, M. Mia, and K. Rahman, "In-store losses of rice and ways of reducing such losses at farmers' level: An assessment in selected regions of Bangladesh," Journal of the Bangladesh Agricultural University, vol. 10, no. 45-60, pp. 133-144, 2012. doi: https://doi.org/10.3329/jbau.v10i1.12105

[44] Food and Agriculture Organization, "Grain storage techniques. evolution and trends in developing countries." [Online]. Available: https://bit.ly/32bs6QB

[45] J. Hayma, The Storage of Tropical Agricultural Products. Wageningen, Netherlands: Agromisa Foundation, 2003.

[46] R. Boxall, "Damage and loss caused by the larger grain borer prostephanus truncatus," Integrated Pest Management Reviews, vol. 7, no. 2, pp. 105-121, 2002.

[47] L. Tapondjou, C. Adler, H. Bouda, and D. Fontem, "Efficacy of powder and essential oil from chenopodium ambrosioides leaves as post-harvest grain protectants against six-stored product beetles," Journal of Stored Products Research, vol. 38, no. 4, pp. 395-402, 2002. doi: https://doi.org/10.1016/s0022-474x(01)00044-3

[48] C. Pantenius, "Storage losses in traditional maize granaries in Togo," International Journal of Tropical Insect Science, vol. 9, no. 6, pp. 725-735, 1988. doi: https://doi.org/10.1017/s1742758400005610

[49] A. Haile, On-Farm Storage of Chickpea, Sorghum and Wheat in Eritrea. Oslo, Norway: Drylands Coordination Group, 2006.

[50] N. Magan and D. Aldred, "Post-harvest control strategies: Minimizing mycotoxins in the food chain," International Journal of Food Microbiology, vol. 119, no. 1-2, pp. 131-139, 2007. doi: https://doi.org/10.1016/j.ijfoodmicro.2007.07. 034

[51] R. Kumar, A. K. Mishra, N. Dubey, and Y. Tripathi, "Evaluation of chenopodium ambrosioides oil as a potential source of antifungal, antiaflatoxigenic and antioxidant activity," International Journal of Food Microbiology, vol. 115, no. 2, pp. 159-164, 2007. doi: https://doi.org/10.1016/j.ijfoodmicro.2006.10.017

[52] M. E. Kimanya, B. De Meulenaer, J. Van Camp, K. Baert, and P. Kolsteren, "Strategies to reduce exposure of fumonisins from complementary foods in rural Tanzania," Maternal \& Child Nutrition, vol. 8, no. 4, pp. 503-511, 2012. doi: https: //doi.org/10.1111/j.1740-8709.2011.00337.x

[53] R. Suleiman, K. Rosentrater, C. Bern et al., "Effects of deterioration parameters on storage of maize: A review," Journal of Natural Sciences Research, vol. 3, no. 9, pp. 147-165, 2013. doi: https://doi.org/10.13031/aim.20131593351

[54] R. A. Suleiman and R. A. Kurt, "Current maize production, postharvest losses and the risk of mycotoxins contamination in tanzania," in ASABE Annual International Meeting, California, CA, 2015.

[55] P. C. Turner, A. Sylla, Y. Y. Gong, M. S. Diallo, A. E. Sutcliffe, A. J. Hall, and C. P. Wild, “Reduction in exposure to carcinogenic aflatoxins by postharvest intervention measures in West Africa: A community-based intervention study," The Lancet, vol. 365, no. 9475, pp. 1950-1956, 2005. doi: https://doi.org/10.1016/s0140-6736(05)66661-5

[56] J. H. Williams, T. D. Phillips, P. E. Jolly, J. K. Stiles, C. M. Jolly, and D. Aggarwal, “Human aflatoxicosis in developing countries: A review of toxicology, exposure, potential health consequences, and interventions," The American Journal of Clinical Nutrition, vol. 80, no. 5, pp. 1106-1122, 2004. doi: https://doi.org/10.1093/ajcn/80.5.1106 
[57] T. Tefera, F. Kanampiu, H. De Groote, J. Hellin, S. Mugo, S. Kimenju, Y. Beyene, P. M. Boddupalli, B. Shiferaw, and M. Banziger, "The metal silo: An effective grain storage technology for reducing post-harvest insect and pathogen losses in maize while improving smallholder farmers' food security in developing countries," Crop Protection, vol. 30, no. 3, pp. 240-245, 2011. doi: https://doi.org/10.1016/j.cropro.2010.11.015

[58] C. Ngosong, C. Tanyi, C. Njume, P. Mfombep, and J. Okolle, "Potential of dual-purpose organic amendment for enhancing tomato (Lycopersicon esculentum M.) performance and mitigating seedling damage by mole cricket (Gryllotalpa Africana spp.)," International Journal of Plant and Soil Science, vol. 20, no. 6, pp. 1-12, 2018. doi: https: //doi.org/10.9734/ijpss/2017/38666

[59] E. Mongyeh, K. Ndamukong, and J. Okolle, "Effects of insecticides with different modes of action in the control of banana weevils (cosmopolites sordidus) in Cameroon," Journal of the Cameroon Academy of Sciences, vol. 12, no. 1, pp. 3-10, 2015.

[60] H. Kouninki, L. Ngamo, T. Hance, and M. Ngassoum, "Potential use of essential oils from local Cameroonian plants for the control of red flour weevil Tribolium castaneum (Herbst.)(Coleoptera: Tenebrionidae)," African Journal of Food, Agriculture, Nutrition and Development, vol. 7, no. 5, pp. 56-70, 2007.

[61] T. B. Raoul and N. T. S. Léonard, "Diversity of stored grain insect pests in the logone valley, from Northern Cameroon to Western Chad Republic in Central Africa,' Journal of Agricultural Science and Technology, vol. 3, no. 9A, pp. 724-745, 2013.

[62] E. Shaaya, M. Kostjukovski, J. Eilberg, and C. Sukprakarn, “Plant oils as fumigants and contact insecticides for the control of stored-product insects," Journal of Stored Products Research, vol. 33, no. 1, pp. 7-15, 1997. doi: https://doi.org/10. 1016/s0022-474x(96)00032-x

[63] W. A. Jonfia-Essien, "Recent developments in the storage of dry cocoa beans in Ghana," in Proceedings of 9th. International Conference on Controlled Atmosphere and Fumigation in Stored Products, Antalya, Turkey, 2012.

[64] L. Quinn, J. de Vos, M. Fernandes-Whaley, C. Roos, H. Bouwman, H. Kylin, R. Pieters, and J. van den Berg, Pesticide use in South Africa: One of the Largest Importers of Pesticides in Africa. London, UK: InTech, 2011.

[65] P. Likhayo, F. Olubayo, and C. Ngatia, "Methyl bromide alternatives for maize grain storage in Kenya," International Journal of Science and Research, vol. 3, no. 7, pp. 2348-2352, 2015.

[66] B. Dahiru, G. Abdullahi, and N. Bukar, "Pesticides use among grain merchants in mubi grain markets of Adamawa state, Nigeria," Agrosearch, vol. 14, no. 1, pp. 1-13, 2014. doi: https://doi.org/10.4314/agrosh.v14i1.1

[67] H. De Groote, S. C. Kimenju, P. Likhayo, F. Kanampiu, T. Tefera, and J. Hellin, "Effectiveness of hermetic systems in controlling maize storage pests in Kenya," Journal of Stored Products Research, vol. 53, pp. 27-36, 2013. doi: https: //doi.org/10.1016/j.jspr.2013.01.001 